Maria Rina T. Reyes-Quintos, MD MClinAud ${ }^{1,2}$.

Regie Lyn P. Santos, MD PhD 1,2 .

Ma. Leah C. Tantoco, MD MClinAud';

Rodante A. Roldan, $\mathrm{MD}^{3}$;

Kathleen R. Fellizar, $\mathrm{MD}^{3}$;

Meliza Anne M. Dalizay-Cruz, BSSP, MClinAud';

Generoso T. Abes, MD MPH',

Charlotte M. Chiong, MD ${ }^{1,2}$

'Philippine National Ear Institute

National Institutes of Health

University of the Philippines Manila

2Department of Otorhinolaryngology

College of Medicine - Philippine General Hospital

University of the Philippines Manila

${ }^{3}$ Department of Otorhinolaryngology

Philippine General Hospital

University of the Philippines Manila
Correspondence: Maria Rina T. Reyes -Quintos, MD, MClinAud Philippine National Ear Institute,

National Institutes of Health -

University of the Philippines Manila

2nd Floor Central Block

Philippine General Hospital

Taft Avenue, Ermita, Manila 1000

Philippines

telefax: (632) 522-0946;

email: info@earinstitute.org.ph

Reprints will not be available from the author.

No funding support was received for this study. The authors signed a disclosure that they have no proprietary or financial interest with any organization that may have a direct interest in the subject matter of this manuscript, or in any product used or cited in this study.

\title{
Otoscopic and Audiologic Findings in an Ati Community in Boracay
}

\begin{abstract}
Background:Certain indigenous populations have been noted by the World Health Organization (WHO) to have the highest prevalence rates for chronic suppurative otitis media (CSOM), including the Australian Aborigines (28-43\%), Greenlanders (2-10\%) and Alaskan Eskimos (2-10\%).
\end{abstract}

Objectives: To determine the prevalence of common ear problems, particularly CSOM, among the indigenous Ati or Aeta community in Bolabog, Boracay, and to determine their hearing sensitivity using screening audiometry.

\section{Methods:}

Study Design - Descriptive cross-sectional study.

Setting - A small Ati community in Bolabog, Boracay.

Population - A total of 63 adults and children underwent medical interview and otoscopy. Additionally 24 had their hearing screened by audiometry.

Results: About a quarter of the population participated in the study, including 41 children ( $40 \%$ of all children) and 22 adults ( $18 \%$ of all adults). Forty-six percent of children and $23 \%$ of adults who were examined had previous history of ear discharge, while $22 \%$ of children and $45 \%$ of adults who were examined had history of hearing loss. Seventeen percent of children had history of hearing loss in the family. CSOM was found in 18 (43.90\%) children and $8(36.36 \%)$ adults. Impacted cerumen was found in $17.1 \%$ of children. Eleven female children underwent screening audiometry. Of these, eight had normal hearing and three had abnormal findings. Thirteen adults were also tested, five of whom were male and had normal hearing bilaterally. Four of eight female adults had abnormal hearing, of which three were unilateral.

Conclusions: The Ati population in Bolabog, Boracay belongs to a group with the highest prevalence rates for CSOM (27.0\%). A bigger sample for screening audiometry is required for proper estimation of hearing loss prevalence. Both environmental and genetic factors may have increased the prevalence of CSOM in the Ati population of Boracay.

Keywords: Hearing loss, chronic suppurative otitis media, Boracay, indigenous community, Ati, Aeta

\section{INTRODUCTION}

Chronic suppurative otitis media (CSOM) is described as persistent middle ear discharge through a tympanic membrane perforation. It is a major cause of preventable hearing loss in the developing world. According to the World Health Organization (WHO), even without otoscopy, it can be assumed that any ear that continues to discharge after 2 months is already CSOM and that an otolaryngologist is able to diagnose CSOM more than $95 \%$ of the time just noting the discharge alone. The most effective means of treating CSOM involves the use of topical antiseptics or antibiotics for at least 2 weeks. In some cases intravenous antibiotics may be required along with surgery.

In 2004, the global burden of CSOM involved 65 to 330 million people, $60 \%$ of whom had significant hearing loss. CSOM caused 28,000 deaths daily. Ninety percent of CSOM cases are 
found in countries in South-east Asia, the Western Pacific Region and Africa and among ethnic minorities along the Pacific rim. The prevalence rate of CSOM is classified by the WHO as belonging to the following groups: lowest if $<1 \%$; low if $1-2 \%$; high if $2-4 \%$; and highest if $>4 \%$. The Philippines is noted to have a high prevalence rate of $2-4 \%$ but the populations with the highest prevalence rates are in Tanzania, India, Solomon Islands, and Guam (>4). Certain indigenous groups also belong to the group with the highest prevalence of CSOM such as the Australian Aborigines (28-43\%), Greenlanders (2-10\%) and Alaskan Eskimos (2-10\%). ${ }^{1,2}$

The Ati is one of several indigenous populations in the Philippines. They are dark-complexioned, small-framed, short in stature, often frizzyhaired people found all over the archipelago from northeastern Luzon to the Visayan Islands and to the northeastern interior of Mindanao. ${ }^{3}$ Our study focused on an Ati community in Bolabog in the Visayan island of Boracay. The Ati community in Bolabog, Boracay is composed of more than 200 individuals who belong to over 40 households. They live in wooden homes of approximately 4 meters by 5 meters clustered closely together with an average of 5 family members per household. They work as laborers either as carpenters and beach sweepers earning 125 to 150 pesos a day. They also receive private donations through the Sisters of Charity, St. Vincent de Paul. According to a volunteer pediatrician who routinely checks the children, the children are generally poorly nourished and underweight and their ears have never been evaluated medically.

This study aims to determine the prevalence of common ear problems, particularly CSOM, among the Ati in Bolabog, Boracay, and to determine their hearing sensitivity using screening audiometry.

\section{METHODS}

This is a descriptive cross-sectional study. Initially, the community was organized through communication with the lead sister from the Sisters of Charity, St. Vincent de Paul. Community consent for the study was taken.

Included in the study are those who consent to have their ears checked and tested, while excluded from the audiologic screening are those who cannot follow testing instructions and those with impacted cerumen and actively discharging ears due to ear infection.

A questionnaire was administered by trained personnel. This contained information about name, age, occupation, present health, history of ear and hearing problems and treatment that they might have undergone. Otoscopy was performed by an otolaryngologist. Appearance of the ear canal and tympanic membrane and presence of ear wax/cerumen, ear discharge and ear infection were documented. Cerumenolytics and antibiotic otic drops were given to those with impacted cerumen and suppurative otitis media, respectively. The medicines were left to the care of the Sisters of Charity who were advised on how to administer the drops and to coordinate with the local physician for patient follow-up.

The hearing test was done using a screening audiometer (model MT-3A made by Nagashima Medical Instruments Company Ltd, Tokyo,
Japan) in a separate room. Ambient noise was documented using a sound level meter (model TES1350A made by TES Electrical Electronic Corp., Taiwan, R.O.C.).

Prevalence rate of CSOM, other ear pathologies and hearing loss were calculated.

\section{RESULTS}

Based on a local registry, the Ati population in Bolabog, Boracay is composed of 222 individuals, including 119 adults and 103 children. Sixty-three individuals participated in the study $(28.38 \%$ of the entire population): 41 were children ( $40 \%$ of all children) and 22 adults (18\% of all adults).

\section{Otologic History}

Majority of the participants were children and most were female (Table 1). Nineteen (46.3\%) children and five (22.7\%) adults had previous history of ear discharge, while nine (22.0\%) children and ten (45.5\%) adults had history of hearing loss. This makes the overall percentage of individuals with previous history of ear discharge to 38.1 and of hearing loss to 30.2 . Seventeen percent of children (7 of 41) had history of hearing loss in the family.

\section{Table 1. Number of study participants according to age group and sex}

\begin{tabular}{|c|c|c|c|}
\hline & N Male (\%) & N Female (\%) & N Total (\% by age group) \\
\hline Children* & $17(41.5)$ & $24(58.5)$ & $41(61.5)$ \\
\hline Adults & $7(31.8)$ & $15(68.2)$ & $22(34.9)$ \\
\hline Total & $24(38.1)$ & $39(61.9)$ & 63 \\
\hline
\end{tabular}

Table 2. Otoscopic findings by age group and sex*

\begin{tabular}{|c|c|c|c|}
\hline Otoscopic finding & Male Children & Female Children & Female Adults \\
\hline Impacted cerumen & $\begin{array}{l}\text { Bilateral:3 } \\
\text { Unilateral:1 }\end{array}$ & $\begin{array}{l}\text { Bilateral:1 } \\
\text { Unilateral:2 }\end{array}$ & None \\
\hline Otitis media with effusion & $\begin{array}{l}\text { Bilateral:0 } \\
\text { Unilateral: } 1\end{array}$ & $\begin{array}{l}\text { Bilateral:2 } \\
\text { Unilateral: } 1\end{array}$ & $\begin{array}{l}\text { Bilateral:0 } \\
\text { Unilateral: } 1\end{array}$ \\
\hline Perforated eardrum, dry & None & $\begin{array}{l}\text { Bilateral: } 0 \\
\text { Unilateral: } 3\end{array}$ & $\begin{array}{l}\text { Bilateral:0 } \\
\text { Unilateral:2 }\end{array}$ \\
\hline Perforated eardrum, wet & $\begin{array}{l}\text { Bilateral:3 } \\
\text { Unilateral: } 1\end{array}$ & None & $\begin{array}{l}\text { Bilateral: } 1 \\
\text { Unilateral:3 }\end{array}$ \\
\hline Active discharge & $\begin{array}{l}\text { Bilateral:2 } \\
\text { Unilateral: } 1\end{array}$ & $\begin{array}{l}\text { Bilateral:3 } \\
\text { Unilateral: } 1\end{array}$ & $\begin{array}{l}\text { Bilateral:0 } \\
\text { Unilateral: } 1\end{array}$ \\
\hline
\end{tabular}

\section{Otoscopic Findings}

The otoscopic findings according to age group and gender are presented in Table 2. Impacted cerumen was found in 7 (17.1\%) 
ORIGINAL ARTICLES

children; otitis media with effusion in 4 (9.8\%) children and 1 (4.5\%) adult; perforated tympanic membrane (dry) in 3 (7.3\%) children and 2 (9.1\%) adults; CSOM and active ear discharge in 11 (26.8\%) children and $6(27.3 \%)$ adults; and otomycosis in 1 (4.5\%) adult. The overall prevalence of CSOM among the Ati participants is therefore $27.0 \%$. Impacted cerumen was also common among children, with a prevalence of $17.1 \%$ (equivalent to $11.1 \%$ of entire population tested).

Using otoscopy as gold standard for diagnosing chronic otitis media, history of ear discharge showed a sensitivity of $93.8 \%$ and specificity of $80.0 \%$.

\section{Audiologic Findings}

Audiologic screening was done in a relatively quiet room with background noise of 49 to $60 \mathrm{dBA}$, averaging $55 \mathrm{dBA}$ when tested every 30 minutes. Because of the high ambient noise in the room normal hearing thresholds were determined to be $40 \mathrm{~dB}$ across frequencies $(500-4000 \mathrm{~Hz})$.

Eleven female children underwent screening audiometry. Eight children had normal hearing while 3 children had abnormal findings (1 unilateral). Five male and 8 female adults were also tested. All the males had bilaterally normal hearing. Four females had normal hearing bilaterally and 4 had abnormal hearing ( 3 unilateral). None of those with CSOM and actively discharging ears were tested.

Using screening audiometry as a gold standard for hearing, history taking for hearing loss alone showed a sensitivity of $20 \%$ for children and $80 \%$ for adults and a specificity of $33 \%$ for children and $80 \%$ for adults.

\section{DISCUSSION}

The Ati in Bolabog, Boracay belongs to the group with the highest CSOM prevalence rates (27\%) based on the WHO classification. It is much higher than the overall prevalence rate in the Philippines and is approaching the prevalence rate of the Australian Aborigines which currently has the highest rate. This could be due to observed overcrowding in the homes, poor hygiene, poor nutrition, poor access to health care $^{4}$ and possible genetic factors ${ }^{5}$ leading to predisposition to poor immune resistance. Interestingly the Ati community is composed of a handful of families that intermarried through generations, thus, consanguinity and increased sharing of genetic material may play a role in greater predisposition to CSOM. This is further strengthened by the similar environmental background and lifestyle factors that all individuals in the community are exposed to.

Audiologic tests were not done for all participants because many of the children were too young to follow instructions. During testing most of the adult males were at work, while many of the younger children were available for testing. Also the presence of active ear discharge and failure to obtain consent precluded audiologic testing in many cases. On the other hand, the presence of drainage in the ear is highly indicative of hearing loss. Only $10.8 \%$ of the population was tested with audiometry. Thus the prevalence estimate of $29.2 \%$ (7 of 24) for documented hearing impairment may not be reflective of the entire community.

Predisposing factors such as personal history and family history of hearing loss had low sensitivity and specificity in detecting hearing loss in children, while history of hearing loss in adults is sensitive and specific. Also, history of ear discharge is highly sensitive and specific in detecting presence of ear discharge in both children and adults. This means that history alone is very useful in suspecting CSOM, particularly in adults. For children, hearing should be tested objectively (e.g. by play audiometry) to get reliable hearing sensitivity rates.

There were two children and one adult with abnormal audiometric but normal otoscopic findings. In these cases the hearing loss may be due to an inner ear problem and thus formal evaluation of these individuals is needed to determine true hearing sensitivity.

The limitation of this study includes the fact that only $28 \%$ of the entire population was screened, so that the prevalence of CSOM in children is at least $10.7 \%(11 / 103)$ and $5 \%(6 / 119)$ if only those who participated in the study had the disease and as much as $71 \%(73 / 103)$ in children and $86 \%(103 / 119)$ in adults if all of those who did not participate had the disease! In any case, they would still have a high prevalence of CSOM in this population. Also, although we can deduce that the hearing loss from CSOM would be mostly conductive in nature, we were not able to qualify the type of hearing loss in this study.

It is recommended that another visit be done on the community to screen a larger sample of the population, specially the adults. Evaluation of the otologic and audiologic profiles of other Ati communities in the country should also be performed in order to determine possible cultural/environmental and genetic factors that predispose to ear disease. It would also be important to determine the impact of CSOM and hearing loss on the Ati way of life. ${ }^{6,7}$

\section{ACKNOWLEDGMENT:}

We are very grateful to the Sisters of Charity, especially to Sister Vic Ostan, who coordinated the hearing screening mission and acted as translator. We would also like to thank the following: Dr. Romeo L. Villarta Jr. for his invaluable input; Ms. Melquiadesa S. Pedro, Ms. Melody T. Francisco and Ms. Maureen C. Tantoco for their help in gathering data.

\section{REFERENCES:}

1. Acuin J. and Child and Adolescent Health and Development Prevention of Blindness and Deafness. Chronic suppurative otitis media: Burden of illness and management options [monograph on the internet]. Geneva Switzerland: World Health Organization; 2004 [cited $2006 \mathrm{Jul}$ 24]. Available from: http://www.who.int/entity/pbd/deafness/activities/hearing_care/ otitis_media.pdf

2. Stuart, John. Ear disease in aboriginal children - Is prevention an option. From: Conference proceedings medical option for prevention of otitis media in Australian aboriginal infants [monograph on the internet]. Menzie's School of Health Research and the Australian Doctor's Fund Darwin North Territory Australia; 1992 [cited 2006 Jul 24]. Available from: www.cybrary. uq.edu.au/library.uq/gmc/images/gmc035.pdf

3. Roces, AR, editor. Filipino heritage: the making of a nation. Vol 1. Singapore: Times Printers Sdn. Blnd.

4. Morris PS, Leach AJ, Silberberg P, Mellon G, Wilson C, Hamilton E, et al. Otitis media in young Aboriginal children from remote communities in Northern and Central Australia: a crosssectional survey. BMC Pediatrics. 2005 Jul [cited 2006 Jul 24];5(27): [about 13 p.]. Available from http://www.biomedcentral.com/1471-2431/5/27

5. Jassar P, Murray P, Wabnitz $D$ and Heldreich $C$. The posterior attic. An observational study of aboriginal Austrians with chronic otitis meida (COM) and a theory to the low incidence of cholesteatomatous otitis media versus the high rate of mucosal otitis media. Int J of Pediatr Otorhinolaryngol. 2005 Nov; 70: 1165-1167.

6. Scaldwell WA. Effect of otitis media upon reading scores of Indian children in Ontario. Ann Otol Rhinol Laryngol. 1989 Mar;98(3):200-1.

7. Auinger $\mathrm{P}$, Lanphear BP, Kalkwarf $\mathrm{H}$, and Mansour M. trends in otitis media among children in the United States. Pediatrics.2003 Sept [cited 2006 July 24]; 112(3): [about 6 p.]. Available from: http://www.pediatrics.aappublications.org/cgi/content/abstract/112/3/514 